\title{
DEMAND IN INDONESIAN DOMESTIC AIR TRAVEL MARKET AFTER DEREGULATION
}

\author{
Basri Fahriza ${ }^{1,2}$, Frank Willey ${ }^{1}$ \\ 1. RMIT University, 2. STMT Trisakti. \\ $\triangle$ corresponding author: basrifahriza@gmail.com
}

\begin{abstract}
This research is exploring the change of domestic air travel market demand in Indonesia prior and post deregulation. Changes on policies in Indonesian aviation were contributed to the present day market. This historical overview will examine the 'oligopoly policy' with only five airlines and the deregulation process that began in 1999. The research then analyses the demand for domestic air travel. Exponential Moving Average Growth were using to analysing data to forecasting the number of passenger from year 2007 to 2015 in yearly basis. Demand is then analysed on three separate airline routes in Indonesia they are Jakarta-Medan, Jakarta-Surabaya, and Jakarta-Pontianak.

Keywords: Demand, Domestic Air Travel, Deregulation, Passeneger, Indonesia.
\end{abstract}

\section{Introduction}

Deregulation in Indonesia start when governments remove restrictions on airlines business Indonesia to encourage the efficient, competitive and consumer oriented marketplace in Indonesian airline industry (Williams, 1993). Secretary General of the Ministry of Communications Anwar Suprijadi said the decision to deregulate was taken in a bid to promote fair competition in domestic airline services, ("Govt insists on licensing more airlines," 1999). And resulting numbers of new Indonesian airlines emerged predominantly mostly in the cut-fare sector including Lion Air; Indonesia's Air Asia, former Adam Air, former Batavia Air and Sriwijaya Air, radically changing the nature of the airline business in Indonesia with present of low cost carrier.

This research is to identifying the change of demand in Indonesian domestic travel market prior and post deregulation. To develop this finding researcher set limitation to focus on three main routes as samples. The route examined is Jakarta-Surabaya, Jakarta-Medan and Jakarta - Pontianak. The route was chosen based on our judgement that Surabaya and Medan were representing high dense city population while Pontianak was representing medium city dense population. 


\section{Method}

Researcher used quantitative and qualitative techniques approach. Quantitative data was analyzed through Time series by Exponential Moving Average Growth to analyzing data to forecasting the number of passenger in the future year from year 2007 up to 2015 in yearly basis.

The Time Series models by Exponential Moving Average were adopted from (Doganis, 2002). The analyses presented were using the historical data of previous year from year 1995 to year 2006 to find the number of passenger till year 2015. The formulation of analyzing this data shown as follow:

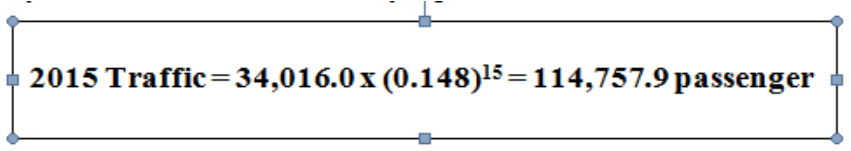

\section{Discussion}

This section presents the time series estimates with exponential Moving average growth and it will diagnostic the air travel market in Indonesia for the future years up to year 2015. This section is divided into four subsections. Each sub-section considers the results for each route. For Jakarta Medan Demand Estimates, researcher identified that number of passengers from 1995 to 1996 was steadily growth and number of passenger on Jakarta - Medan route increase to 530.197 passengers but due to crises in 1997 and getting worsen in 1998 number of passengers on Jakarta - Medan routes slum to 228.665 passengers continue slumming to 197.975 passenger in 1999 as shown at table 1.

Table 1.

\begin{tabular}{|c|c|c|}
\hline \multirow{2}{*}{ YEARS } & \multicolumn{2}{|c|}{ ROUTES } \\
\cline { 2 - 3 } & Jakarta - Medan (CGK-MES) & Medan - Jakarta (MES-CGK) \\
\hline 1995 & 416.731 & 444.673 \\
\hline 1996 & 530.197 & 458.989 \\
\hline 1997 & 456.071 & 441.009 \\
\hline 1998 & 228.665 & 255.237 \\
\hline 1999 & 197.976 & 224.253 \\
\hline 2000 & 253.704 & 270.562 \\
\hline 2001 & 1.304 .998 & 352.297 \\
\hline 2002 & 228.665 & 566.600 \\
\hline 2003 & 520.726 & 832.295 \\
\hline
\end{tabular}


Table 1, cont.

\begin{tabular}{|l|c|c|}
\hline 2004 & 988.401 & 1.108 .647 \\
\hline 2005 & 1.074 .894 & 1.203 .985 \\
\hline 2006 & 1.133 .721 & 1.316 .951 \\
\hline
\end{tabular}

Source: ("Penumpang Pesawat Udara," 2005)

Table 2.

\begin{tabular}{ccccc}
\hline Years & $\begin{array}{c}\text { CGK-MES } \\
\text { Passengers } \\
(\mathbf{0 0 0})\end{array}$ & $\begin{array}{c}\text { Annual } \\
\text { Percentage } \\
\text { Change (\%) }\end{array}$ & $\begin{array}{c}\text { Three year } \\
\text { moving } \\
\text { average } \\
\text { passenger } \\
\mathbf{( 0 0 0 )}\end{array}$ & $\begin{array}{c}\text { Annual } \\
\text { Change (\%) }\end{array}$ \\
1995 & 416.7 & & 467.7 & \\
1996 & 530.2 & 27.2 & 405.0 & -13.4 \\
1997 & 456.1 & -14.0 & 294.2 & -27.3 \\
1998 & 228.7 & -49.9 & 226.8 & -22.9 \\
1999 & 198.0 & -13.4 & 258.9 & 14.2 \\
2000 & 253.7 & 28.1 & 367.4 & 41.9 \\
2001 & 325.0 & 28.1 & 527.8 & 43.7 \\
2002 & 523.4 & 61.1 & 748.9 & 41.9 \\
2003 & 734.9 & 40.4 & 932.7 & 24.5 \\
2004 & 988.4 & 34.5 & 1065.7 & 14.3 \\
2005 & 1074.9 & 8.8 & & \\
2006 & 1133.7 & 5.5 & & \\
\hline
\end{tabular}

The growth of passenger for Jakarta - Medan and Medan Jakarta was growth tremendously after the deregulation. Number of passenger's increase and government set this as fat route. Many airlines operator interested to operate on this route and government was set no restriction for all airlines operator to serve this route or just to increase frequency. Impact on government decision has made the flight frequencies of Jakarta - Medan and Medan - Jakarta this condition also brought the positive growth number of passenger as shows in table 1 .

Based on researcher calculation shown on table 2 exponential moving average growth calculation for Jakarta - Medan Route and table 4 exponential moving average growth calculation for Medan - Jakarta Route shown the numbers of forecasting passengers from Jakarta to Medan and Medan to Jakarta will keep growing. Through this model researcher found that the grow rate for Jakarta - Medan route in the future is $13 \%$ and Medan 
- Jakarta is $14.6 \%$. This rate used to finding the number of passenger in future year from year 2007 to year 2015 for both direction routes.

Table 3 exponential moving average growth result for Jakarta Medan routes from 2007 to 2015 show number passenger forecasted for Jakarta - Medan route for year 2008 will be 1.537 .700 passengers and it will keep growing up to year 2015 with about 3.617 .500 passengers, while on table 5 exponential moving average growth result for Medan - Jakarta routes from 2007 to 2015 the passengers on Medan - Jakarta route will higher than Jakarta - Medan or about 1.820 .900 passengers in 2008 and will grow to 4.727.000 passengers in 2015 it still higher than Jakarta - Medan routes.

Table 3.

\begin{tabular}{|c|c|}
\hline Years & $\begin{array}{c}\text { CGK-MES } \\
\text { Passengers (000) }\end{array}$ \\
\hline 2007 & 1360.8 \\
\hline 2008 & 1537.7 \\
\hline 2009 & 1737.6 \\
\hline 2010 & 1963.4 \\
\hline 2011 & 2218.7 \\
\hline 2012 & 2507.1 \\
\hline 2013 & 2833.0 \\
\hline 2014 & 3201.3 \\
\hline 2015 & 3617.5 \\
\hline
\end{tabular}

There are possibilities passengers are using other mode of transportation such bus, ship or using private car. Transportation substitution will not significantly change the number of passenger on this route as due to large population in Indonesia and the economic grow.

Intention to made Medan as an International hub to compete with Singapore, Kuala Lumpur and Bangkok might potentially increase number of passenger to Medan. In year 2006 flight frequencies on flight Jakarta Medan is 37 flights a day and serves with only single runway. This problem might be solving if the new airport open by end of year 2009 with bigger capacity and maximum landing weight and may accept A380. 
Table 4.

\begin{tabular}{|c|c|c|c|c|}
\hline Years & $\begin{array}{c}\text { MES-CGK } \\
\text { Passengers } \\
\mathbf{( 0 0 0 )}\end{array}$ & $\begin{array}{c}\text { Annual } \\
\text { Percentage } \\
\text { Change (\%) }\end{array}$ & $\begin{array}{c}\text { Three year } \\
\text { moving average } \\
\text { passenger (000) }\end{array}$ & $\begin{array}{c}\text { Annual Change } \\
\text { (\%) }\end{array}$ \\
\hline 1995 & 444.7 & 3.2 & 448.2 & -14.1 \\
\hline 1996 & 458.9 & -3.9 & 385.0 & -20.3 \\
\hline 1997 & 441.0 & -42.1 & 306.8 & -18.5 \\
\hline 1998 & 255.2 & -12.1 & 250.0 & 12.9 \\
\hline 1999 & 224.3 & 20.7 & 282.4 & 40.4 \\
\hline 2000 & 270.6 & 30.2 & 396.5 & 47.2 \\
\hline 2001 & 352.3 & 60.8 & 583.7 & 43.2 \\
\hline 2002 & 566.6 & 46.9 & 835.8 & 25.4 \\
\hline 2003 & 832.3 & 33.2 & 1048.3 & 15.4 \\
\hline 2004 & 1108.6 & 8.6 & 1209.9 & \\
\hline 2005 & 1204.0 & 9.4 & & \\
\hline 2006 & 1317.0 & & & \\
\hline
\end{tabular}

For Jakarta-Surabaya Demand Estimates, Surabaya is the second largest city in Indonesia after Jakarta. Surabaya is the popular destination among the Jakarta's people the flight frequency for Jakarta - Surabaya and Surabaya - Jakarta is 234 flights per week in 2001 and become 399 flights per week in 2007 or equal with 57 flight per day and put Jakarta - Surabaya route as the most popular city by serving the most frequent flight between two cites and followed by Jakarta - Medan route 39 flights a day.

Even though number of passenger for Jakarta- Surabaya or Surabaya Jakarta is very fluctuate and it will be difficult to predict the future demand. On table 6 Jakarta - Surabaya vice versa Traffic from 1995 - 2006 the number of passenger in year 2002 is higher than in year 2003 while the flight frequency between Jakarta and Surabaya in year 2003 was higher with 357 flights a week compare with year 2002 with only 226 flights per week. Surprisingly in 2005 numbers of passenger increasing drastically compare from previous year with $203 \%$ growth or about 1.588 .416 passengers for Jakarta Surabaya route and $70 \%$ for Surabaya - Jakarta route with 1.203.985 passengers. 
Table 5.

\begin{tabular}{|c|c|c|}
\hline \multirow{2}{*}{ YEARS } & \multicolumn{2}{|c|}{ ROUTES } \\
\cline { 2 - 3 } & Jakarta - Surabaya (CGK-SUB) & Surabaya - Jakarta (SUB-CGK) \\
\hline 1995 & 753.426 & 789.256 \\
\hline 1996 & 779.011 & 820.896 \\
\hline 1997 & 764.848 & 804.809 \\
\hline 1998 & 379.061 & 400.358 \\
\hline 1999 & 315.787 & 386.507 \\
\hline 2000 & 450.184 & 507.762 \\
\hline 2001 & 537.959 & 576.766 \\
\hline 2002 & 823.511 & 566.600 \\
\hline 2003 & 520.726 & 475.763 \\
\hline 2004 & 523.796 & 707.967 \\
\hline 2005 & 1.588 .416 & 1.203 .985 \\
\hline 2006 & 1.569 .966 & 1.683 .118 \\
\hline
\end{tabular}

Source: ("Penumpang Pesawat Udara," 2005)

Surabaya airport have good infrastructure with new terminal with bigger capacity and bigger apron to accommodate large number of aircraft serving Surabaya. On table 7 exponential moving average growth calculation for Jakarta - Surabaya Route and table 8 exponential moving average growth result for Jakarta - Surabaya route from 2007 to 2015 researcher calculate the number of passenger with growth rate $8.3 \%$ for Jakarta - Surabaya route and 7\% for Surabaya - Jakarta route.

The result of the forecasting for both directions are shows on table 8 exponential moving average growth result for Jakarta - Surabaya route from 2007 to 2015 and table 9 exponential moving average growth result for Surabaya - Jakarta route from 2007 to 2015. The Jakarta Surabaya route will reach number 2.724.400 passengers in 2015 whiles the Surabaya - Jakarta will reach 2.438 .900 passengers as shown on table 10 or lower than Jakarta - Surabaya.

Table 6.

\begin{tabular}{|c|c|c|c|c|}
\hline Years & $\begin{array}{c}\text { CGK-SUB } \\
\text { Passengers } \\
\mathbf{( 0 0 0 )}\end{array}$ & $\begin{array}{c}\text { Annual } \\
\text { Percentage } \\
\text { Change (\%) }\end{array}$ & $\begin{array}{c}\text { Three year } \\
\text { moving average } \\
\text { passenger (000) }\end{array}$ & $\begin{array}{c}\text { Annual Change } \\
(\%)\end{array}$ \\
\hline 1995 & 753.4 & 3.4 & 765.8 & \\
\hline 1996 & 779.0 & -1.8 & 641.0 & -16.3 \\
\hline 1997 & 764.8 & -50.4 & 486.6 & -24.1 \\
\hline 1998 & 379.1 & -16.7 & 381.7 & -21.6 \\
\hline 1999 & 315.8 & & & \\
\hline
\end{tabular}


Table 6, cont.

\begin{tabular}{|c|c|c|c|c|}
\hline 2000 & 450.2 & 42.6 & 434.6 & 13.9 \\
\hline 2001 & 538.0 & 19.5 & 603.9 & 38.9 \\
\hline 2002 & 823.5 & 53.1 & 627.4 & 3.9 \\
\hline 2003 & 520.7 & -36.8 & 622.7 & -0.8 \\
\hline 2004 & 523.8 & 0.6 & 877.6 & 40.9 \\
\hline 2005 & 1588.4 & 203.3 & 1227.4 & 39.9 \\
\hline 2006 & 1570.0 & -1.2 & & \\
\hline
\end{tabular}

Table 7.

\begin{tabular}{|c|c|}
\hline Years & $\begin{array}{c}\text { CGK-SUB } \\
\text { Passengers (000) }\end{array}$ \\
\hline 2007 & 1439.6 \\
\hline 2008 & 1559.1 \\
\hline 2009 & 1688.5 \\
\hline 2010 & 1828.6 \\
\hline 2011 & 1980.4 \\
\hline 2012 & 2144.8 \\
\hline 2013 & 2322.8 \\
\hline 2014 & 2515.6 \\
\hline 2015 & 2724.4 \\
\hline
\end{tabular}

The lower percentage growth for Surabaya compares than Jakarta Medan might cause Surabaya located on the same island with Jakarta were passengers have options to choose other mode of transportation as substitutes to travelling to Surabaya. Flight frequencies between Surabaya and Jakarta and Surabaya to Jakarta will keep increasing with lower than $10 \%$ growth.

Table 8.

\begin{tabular}{|c|c|c|c|c|}
\hline Years & $\begin{array}{c}\text { SUB-CGK } \\
\text { Passengers } \\
\mathbf{( 0 0 0 )}\end{array}$ & $\begin{array}{c}\text { Annual } \\
\text { Percentage } \\
\text { Change (\%) }\end{array}$ & $\begin{array}{c}\text { Three year } \\
\text { moving average } \\
\text { passenger (000) }\end{array}$ & $\begin{array}{c}\text { Annual Change } \\
\text { (\%) }\end{array}$ \\
\hline 1995 & 789.3 & & & \\
\hline 1996 & 820.9 & 4.0 & 805.0 & -16.1 \\
\hline 1997 & 804.8 & -2.0 & 675.3 & -21.4 \\
\hline 1998 & 400.4 & -50.3 & 530.6 & -18.7 \\
\hline 1999 & 386.5 & -3.5 & 431.5 & 13.6 \\
\hline 2000 & 507.8 & 31.4 & 490.3 & \\
\hline
\end{tabular}


Table 8, cont.

\begin{tabular}{|c|c|c|c|c|}
\hline 2001 & 576.8 & 13.6 & 550.4 & 12.2 \\
\hline 2002 & 566.6 & -1.8 & 539.7 & -1.9 \\
\hline 2003 & 475.8 & -16.0 & 583.4 & 8.1 \\
\hline 2004 & 708.0 & 48.8 & 795.9 & 36.4 \\
\hline 2005 & 1204.0 & 70.1 & 1198.4 & 50.6 \\
\hline 2006 & 1683.1 & 39.8 & & \\
\hline
\end{tabular}

Table 9.

\begin{tabular}{|c|c|}
\hline Years & $\begin{array}{c}\text { SUB-CGK } \\
\text { Passengers (000) }\end{array}$ \\
\hline 2007 & 1372.0 \\
\hline 2008 & 1468.0 \\
\hline 2009 & 1570.8 \\
\hline 2010 & 1680.8 \\
\hline 2011 & 1798.4 \\
\hline 2012 & 1924.3 \\
\hline 2013 & 2059.0 \\
\hline 2014 & 2203.1 \\
\hline 2015 & 2438.9 \\
\hline
\end{tabular}

For Jakarta - Pontianak demand estimates, Pontianak is one of growth city in Kalimantan or Borneo Island beside Balikpapan. Many of Pontianak's migrate to Jakarta to doing business mostly the Pontianak's Chinese followed with the Malay and Dayaks. Many seasonal events in Pontianak attract the passenger to travel to Pontianak to celebrate many Chinese festivals within a year.

Table 10.

\begin{tabular}{|c|c|c|}
\hline \multirow{2}{*}{ YEARS } & \multicolumn{2}{|c|}{ ROUTES } \\
\cline { 2 - 3 } & Jakarta - Pontianak (CGK-PNK) & Pontianak - Jakarta (PNK-CGK) \\
\hline 1995 & 191.404 & 188.172 \\
\hline 1996 & 210.495 & 190.503 \\
\hline 1997 & 156.308 & 149.161 \\
\hline 1998 & 162.209 & 153.970 \\
\hline 1999 & 119.041 & 128.352 \\
\hline 2000 & 158.434 & 161.807 \\
\hline 2001 & 221.047 & 226.274 \\
\hline 2002 & 239.859 & 247.720 \\
\hline 2003 & 320.326 & 337.584 \\
\hline 2004 & 402.277 & 424.430 \\
\hline 2005 & 399.543 & 431.641 \\
\hline 2006 & 424.747 & 463.114 \\
\hline
\end{tabular}

Source: ("Penumpang Pesawat Udara," 2005) 
The number of passenger as show on table 11 Jakarta - Pontianak vice versa traffic from 1995 - 2006 for Jakarta - Pontianak and Pontianak - Jakarta is not fluctuated drastically the annual change for both direction routes is lower than $40 \%$. Number of passenger keep growing event though in some years there relatively small decreasing in number of passengers.

Table 11.

\begin{tabular}{|c|c|c|c|c|}
\hline Years & $\begin{array}{c}\text { CGK-PNK } \\
\text { Passengers } \\
\mathbf{( 0 0 0 )}\end{array}$ & $\begin{array}{c}\text { Annual } \\
\text { Percentage } \\
\text { Change (\%) }\end{array}$ & $\begin{array}{c}\text { Three year } \\
\text { moving average } \\
\text { passenger (000) }\end{array}$ & $\begin{array}{c}\text { Annual Change } \\
\text { (\%) }\end{array}$ \\
\hline 1995 & 191.4 & 10.0 & 186.1 & \\
\hline 1996 & 210.5 & -25.8 & 176.4 & -5.2 \\
\hline 1997 & 156.3 & 3.8 & 145.9 & -17.3 \\
\hline 1998 & 162.2 & -26.6 & 146.6 & 0.5 \\
\hline 1999 & 119.0 & 33.1 & 166.2 & 24.2 \\
\hline 2000 & 158.4 & 39.5 & 206.4 & 23.1 \\
\hline 2001 & 221.0 & 8.5 & 260.4 & 16.6 \\
\hline 2002 & 239.9 & 33.5 & 320.8 & 9.3 \\
\hline 2003 & 320.3 & 25.6 & 374.0 & \\
\hline 2004 & 402.3 & -0.7 & 408.9 & \\
\hline 2005 & 399.5 & 6.3 & & \\
\hline 2006 & 424.7 & & & \\
\hline
\end{tabular}

Government also attempted the transmigration program to live and settle in West Kalimantan or beyond Pontianak increasing number of population in this region. Most of the people who transmigrate are from West Java and from Central Java this trend will strengthen the growth of passenger between Jakarta and Pontianak with movement of people between these two cities.

Table 12.

\begin{tabular}{|c|c|}
\hline Years & $\begin{array}{c}\text { CGK-PNK } \\
\text { Passengers (000) }\end{array}$ \\
\hline 2007 & 495.6 \\
\hline 2008 & 545.7 \\
\hline 2009 & 600.8 \\
\hline 2010 & 661.5 \\
\hline 2011 & 728.3 \\
\hline
\end{tabular}


Table 12, cont.

\begin{tabular}{|l|l|}
\hline 2012 & 801.8 \\
\hline 2013 & 882.8 \\
\hline 2014 & 972.0 \\
\hline
\end{tabular}

Table 13.

\begin{tabular}{|c|c|c|c|c|}
\hline Years & $\begin{array}{c}\text { PNK-CGK } \\
\text { Passengers } \\
\mathbf{( 0 0 0 )}\end{array}$ & $\begin{array}{c}\text { Annual } \\
\text { Percentage } \\
\text { Change (\%) }\end{array}$ & $\begin{array}{c}\text { Three year } \\
\text { moving average } \\
\text { passenger (000) }\end{array}$ & $\begin{array}{c}\text { Annual Change } \\
(\%)\end{array}$ \\
\hline 1995 & 188.2 & & & \\
\hline 1996 & 190.5 & 1.2 & 175.9 & -6.5 \\
\hline 1997 & 149.2 & -21.7 & 164.5 & -12.6 \\
\hline 1998 & 154.0 & 3.2 & 143.8 & 2.9 \\
\hline 1999 & 128.4 & -16.6 & 148.0 & 16.3 \\
\hline 2000 & 161.8 & 26.1 & 172.1 & 23.1 \\
\hline 2001 & 226.3 & 39.8 & 211.9 & 27.6 \\
\hline 2002 & 247.7 & 9.5 & 270.5 & 18.2 \\
\hline 2003 & 337.6 & 36.3 & 336.6 & 10.5 \\
\hline 2004 & 424.4 & 25.7 & 397.9 & \\
\hline 2005 & 431.6 & 1.7 & 439.7 & \\
\hline 2006 & 463.1 & 7.3 & & \\
\hline
\end{tabular}

Based on the calculation on table 12 exponential moving average growth calculation for Jakarta - Pontianak route and table 14 the number of growth passenger for Jakarta - Pontianak is $10.1 \%$ while the Pontianak Jakarta growth passenger is $11.6 \%$. Number of passengers for Jakarta Pontianak will be reach level 1 million passengers in 2015 as shown at table 13 and Pontianak - Jakarta reach level 1 million passengers in 2013 as shown table 15. Passengers travelling between Jakarta and Pontianak only have one transportation substitution by sea with offer lower price compare travelling by air.

Table 14.

\begin{tabular}{|c|c|}
\hline Years & $\begin{array}{c}\text { PNK-CGK } \\
\text { Passengers (000) }\end{array}$ \\
\hline 2007 & 547.7 \\
\hline 2008 & 611.2 \\
\hline 2009 & 682.1 \\
\hline
\end{tabular}


Table 14, cont.

\begin{tabular}{|l|l|}
\hline 2010 & 761.2 \\
\hline 2011 & 849.5 \\
\hline 2012 & 948.1 \\
\hline 2013 & 1057.1 \\
\hline 2014 & 1180.8 \\
\hline 2015 & 1307.4 \\
\hline
\end{tabular}

For Indonesia air travel market estimates, we discuss the whole Indonesian domestic travel market. Based on research calculation as show on table 16 the number of passenger in Indonesian domestic travel market is increase tremendously compare prior of deregulation, the same table describe the annual change growth percentage increase mostly between year 2002 to year 2003 reach $56 \%$.

Indonesia travel market is quite immune from any turbulence that hit the international market such as Bali bomb the first and second, SARS and the increasing of oil price. Between that periods Indonesian domestic travel market keep showing fantastic grow till now.

Based on this research the number of passenger in Indonesia will keep going show it fantastic number of growing as show on table 17 the number of passenger will reach level 114.757 .900 passenger in 2015 with growth $14.8 \%$ based on calculation on table 16 .

Table 15.

\begin{tabular}{|c|c|c|c|c|}
\hline Years & $\begin{array}{c}\text { INDONESIA } \\
\text { Passengers } \\
\mathbf{( 0 0 0 )}\end{array}$ & $\begin{array}{c}\text { Annual } \\
\text { Percentage } \\
\text { Change (\%) }\end{array}$ & $\begin{array}{c}\text { Three year } \\
\text { moving average } \\
\text { passenger (000) }\end{array}$ & $\begin{array}{c}\text { Annual Change } \\
(\%)\end{array}$ \\
\hline 1996 & $13,493.8$ & & & $11,297.7$ \\
\hline 1997 & $12,813.5$ & -5.0 & $8,921.6$ & -21.0 \\
\hline 1998 & $7,585.9$ & -40.8 & $7,191.3$ & -19.4 \\
\hline 1999 & $6,365.5$ & -16.1 & $7,718.7$ & 7.3 \\
\hline 2000 & $7,622.6$ & 19.7 & $9,707.9$ & 25.8 \\
\hline 2001 & $9,168.1$ & 20.3 & $13,560.8$ & 39.7 \\
\hline 2002 & $12,333.0$ & 34.5 & $18,426.1$ & 35.9 \\
\hline 2003 & $19,181.3$ & 55.5 & $23,919.6$ & 29.8 \\
\hline 2004 & $23,764.0$ & 23.9 & $28,864.5$ & 20.7 \\
\hline 2005 & $28,813.5$ & 21.2 & & \\
\hline 2006 & $34,016.0$ & 18.1 & & \\
\hline
\end{tabular}


Table 16.

\begin{tabular}{|c|c|}
\hline Years & INDONESIA Passengers (000) \\
\hline 2007 & $38,040.6$ \\
\hline 2008 & $43,670.6$ \\
\hline 2009 & $50,133.9$ \\
\hline 2010 & $57,553.7$ \\
\hline 2011 & $66,071.6$ \\
\hline 2012 & $75,850.2$ \\
\hline 2013 & $87,076.1$ \\
\hline 2014 & $99,963.3$ \\
\hline 2015 & $114,757.9$ \\
\hline
\end{tabular}

Based on this research Indonesian domestic travel market industry will keep growing in the future years. The growth numbers of passengers will supported by the new aviation infrastructures which are ready to use. This new infrastructure enables airlines to increase their flight frequencies where many airports had bigger capacity for serve passenger and their aircraft.

\section{Conclusion}

This research has evaluated the impact of deregulation in Indonesia domestic air travel market. results of time series model of exponential moving average growth for Jakarta - Medan vice versa, Jakarta - Surabaya vice versa, Jakarta - Pontianak vice versa and Indonesian domestic travel market in general showing growth and prove that deregulation was boosting number of passenger in Indonesian domestic air travel market from 6.3 million passengers in 1999 to 34 million passenger in 2007 and will reach 114 million passengers in 2015.

\section{References}

Doganis, R. (2002). Flying off Course "The economics of international airlines." London: Routledge.

Govt insists on licensing more airlines. (1999, November 27). The Jakarta Post.

Penumpang Pesawat Udara. (2005). Retrieved April 1, 2005, from http://www.bps.go.id/leaflet/leaflet-sep-05-eng.pdf

Williams, G. (1993). The Airline Industry and the Impact of Deregulation (Firts edit). New York: Routledge. 